\title{
ESENSI DAN PEMETAAN TEORETISASI MEDIA KOMUNIKASI DALAM PERSPEKTIF KARL MARX
}

\author{
Rustono Farady Marta \\ Ilmu Komunikasi, Universitas Bunda Mulia \\ Alamat surel: rmarta@bundamulia.ac.id / rustonofarady@gmail.com
}

\begin{abstract}
Perspective of Karl Marx lies in the viewpoint of the "economy", because the essence of the theory and its development include macro and micro scope as patterns of thought in economics. Marx as one of the most influential intellectuals of the time. Marx's theory has a direct impact upon closing of age on March 17, 1883 in London. Marx offers basic prepositions in the process theoryzing as normative ideological implications that has, among others through the social class differences were criticized on the conditions of exploitation of the proletariat by the bourgeoisie with the mental control of production in society and create a false consciousness among the proletariat. Marx believed that the mass media are owned by the public suprastuktur and media communications content is dominated by social class.
\end{abstract}

Keywords: Media Communication Theorizing, Karl Marx Perspective

\begin{abstract}
Abstrak
Perspektif pemikiran Karl Marx terletak pada sudut pandang "ekonomi", karena esensi teori dan perkembangannya meliputi lingkup makro dan mikro sebagaimana pola berpikir dalam bidang ekonomi. Marx sebagai salah satu intelektual yang paling berpengaruh dari waktu ke waktu. Teori Marx memiliki dampak langsung setelah menutup usia pada 17 Maret 1883 London. Marx menawarkan preposisi dasar dalam proses teoretisasi sebagai implikasi ideologi normatif yang dimilikinya, antara lain melalui perbedaan kelas sosial yang dikritik dari kondisi eksploitasi kaum proletar oleh borjuis dengan mengontrol mental produksi di masyarakat dan menciptakan kesadaran palsu di kalangan proletariat. Marx percaya bahwa media massa dimiliki oleh masyarakat suprastuktur dan konten media komunikasinya didominasi oleh kelas sosial.
\end{abstract}

Kata kunci : Teoretisasi Media Komunikasi, Perspektif Karl Marx

\section{PENDAHULUAN}

Karl Marx adalah seorang pemikir dan penggagas aliran sosialis, yang juga tokoh besar di bidang ekonomi dan filsafat. Karl Marx (1818-1883), mengemukakan bahwa pengetahuan bukan sekadar sarana untuk memahami masyarakat namun juga sebagai cara untuk membentuk masyarakat. Kebudayaan, bukan suatu arena netral, ia bersifat politis karena menjadi ekspresi relasi kekuasaan sehingga "ide dari kelas berkuasa selalu merupakan ide yang berkuasa dan dominan, artinya kelas yang menguasai kekuatan material di dalam masyarakat pada saat yang sama menguasai kekuatan intelektual dominan (Barker, 2008: 52).

Semasa hidupnya, Karl Marx menuangkan ide-ide dan gagasannya melalui beberapa buku maupun catatan-catatan, yang mempengaruhi tatanan sosial yang ada di masyarakat. Beberapa buku yang sempat diterbitkan antara lain; The german Ideology, Kemiskinan Filsafat, The Communist Manifesto, A Contribution to the Critique of Political Economy, dan yang paling fenomenal adalah Das Kapital. Selain buku-buku tersebut banyak catatan Marx yang tidak diterbitkan karena dirasa ide Marx banyak yang bertentangan dengan pemerintah pada saat itu.

Menurut Marx, kebudayaan bersifat ideologis, ideologi adalah serangkaian ide yang membentuk realitas, sebuah sistem yang merepresentasikan kode bagaimana masyarakat melihat realitas. Dalam teori Marx, ideologi adalah gagasan palsu yang dilanggengkan oleh golongan dominan (Littlejohn, 2002: 211). Karl Marx percaya

Jurnal Bricolage Vol. 2 No. 2 
bahwa masyarakat terbagi atas dua golongan, yakni mereka yang memiliki kekuasaan dan harta; serta mereka yang tidak, sehingga muncullah konflik kelas. Perspektif Marx disebut sebagai dialectical materialism, yang menyatakan bahwa dunia ini diciptakan bukan dari struktur yang statis namun merupakan proses yang dinamis.

Marx berpendapat bahwa proses produksi di masyarakat menentukan masyarakat itu sendiri. Hal ini adalah dasar pemikiran dari Karl Marx, yaitu hubungan superstruktur. Ekonomi merupakan dasar dari semua struktur sosial masyarakat. Dalam sistem kapitalis, profit menentukan produksi sehingga mendominasi buruh (Littlejohn, 2002: 210).

Teori Marx merupakan sebuah kajian kritis yang digunakan untuk memperlihatkan nilai yang tersembunyi dalam realitas yang ada di media. Media yang seharusnya bersifat objektif. Isi pesan media selalu dipandang tidak bebas nilai, hal ini selalu dikaitkan dengan pemerintah dan pemilik modal/media. Dalam komunikasi sendiri akhirnya muncul teori-teori atau kajian yang membahas pengaruh media massa pada masyarakat, khususnya dari aspek teori kritis.

\section{Pemikiran Karl Marx}

Konsep produksi kaum kapitalis menghasilkan tesis umum Marx bahwa realitas adalah dialectical, dimana terdapat kontradiksi dalam kenyataannya (Callinicos, 2004: 136 - 137). Istilah dialektika didasarkan dari pengalaman sehari-hari dalam dialog. Jika dinyatakan sebuah pendapat, pendapat itu akan ditentang oleh pendapat lain, lalu karena tak puas dengan oposisi itu kita berusaha mendamaikan keduanya dengan sebuah pendapat yang lebih lengkap.

Proses tersebut dapat kita rumuskan menjadi tiga tahap. Tahap pertama adalah sebuah tesis, yang memunculkan tahap kedua yaitu antithesis. Dan akhirnya keduanya didamaikan oleh sintesis. Dalam sintesis atau yang dikenal sebagai pendapat ketiga tidak hanya terjadi peniadaan, pembatalan dari kedua oposisi. Karena munculnya sintesis membuat keduanya tidak berlaku. Selain itu, kedua aspek yang beroposisi disimpan dan diangkat ke taraf yang lebih tinggi. Sebab kebenaran keduanya masih dipertahankan dalam sintesis itu. Dalam istilah bahasa Jerman yang mencakup seluruh pengertian ini adalah "aufgehoben."

Mula-mula manusia hidup dalam keadaan komunistis asli tanpa pertentangan kelas, dimana alat-alat produksi menjadi milik bersama (tesis). Kemudian timbul milik pribadi yang menyebabkan adanya kelas pemilik (kaum Kapitalis) dan kelas tanpa milik (kaum proletar yang selalu bertentangan), disebut antitesis. Jurang antara kaum kaya (kapitalis) dan kaum miskin (proletar) semakin dalam. Maka timbulah krisis yang hebat. Akhirnya kaum proletar bersatu mengadakan revolusi perebutan kekuasaan. Maka timbullah diktaktur proletariat dan terwujudlah masyarakat tanpa kelas dimana alat-alat produksi menjadi milik masyarakat atau Negara (sintesis).

Dengan demikian, pengertian dialektika menurut Karl Marx, suatu metode diskusi tertentu dan satu cara tertentu dalam berdebat yang di dalamnya terdapat ide-ide kontradiktif dan pandangan-pandangan yang bertentangan dilontarkan. Masing-masing pandangan itu berupaya menunjukan titiktitik kelemahan dan kesalahan yang ada pada lawannya, berdasarkan pada pengetahuanpengetahuan dan proposisi-proposisi yang sudah diakui. Dengan demikian maka makin berkembang pertentangan antara penafsiran dan penetapan di lapangan pembahasan dan perdebatan, sampai berhenti pada sebuah kesimpulan yang di dalamnya salah satu pandangan yang bertentangan tersebut dipertahankan, atau sampai munculnya cara pandang baru yang merujukkan kelemahan masing-masingnya.

Marx menganut dialektika tersebut dan menempatkan filsafat materialismenya dalam bentuk dialektika murni. Selanjutnya, dialektika moderen menurut klaim-klaim kaum dialektiawan, dianggap hukum berfikir sekaligus realitas. Oleh karena itu, dialektika moderen adalah metode berfikir dan prinsip

Jurnal Bricolage Vol. 2 No. 2 
yang menjadi dasar menetapkan eksistensi dan perkembangan realitas. Gerak pikiran tidak lain hanyalah cerminan dari suatu gerak realitas yang berusaha dipindahkan dan ditransformasikan ke dalam benak manusia.

Teori media komunikasi menurut Marx mengasumsikan media sebagai arena pertarungan ideologi berbagai kelas. Dalam perspektifnya, para professional media menikmati suatu "ilusi" otonomi dan tersosialisasikan dalam kerangka norma budaya dominan. Media dianggap memiliki kerangka interpretasi yang sesuai dengan budaya dominan. Sementara itu, khalayak media sendiri lebih sering menegaskan dan mengontekskan kerangka tersebut karena ketidaksiapan menghadapi sistem makna alternatif yang memungkinkan mereka menolak definisi yang ditawarkan media secara konsisten.

\section{Pemetaan Teori Media}

Sudut pandang yang dapat kita gunakan untuk melihat peran pemilik media dari segi ekonomi politik terhadap media massa dapat ditempuh dengan menggunakan pandangan dari teori ekonomi politik. Teori Ekonomi-politik merupakan sebuah teori yang berangkat dari pendekatan kritis yang muncul sebagai respon terhadap akselerasi kapitalisme. Ekonomi politik secara umum digunakan untuk mendeskripsikan hubungan antara sistem ekonomi, sistem politik dan sistem komunikasi dalam struktur kapitalisme global. Teori ini fokus pada hubungan antara struktur ekonomi, dinamika industri media, dan ideologi media (yang pada akhirnya tercermin dalam isi media tersebut). Media (massa) tidak lebih dari satu bagian dalam sistem ekonomi yang juga sangat dekat pada sistem politik. Teori ini menjelaskan bahwa pasar dan ideologi memiliki pengaruh besar dalam penentuan isi (content) media. Perbedaan isi media antara satu dengan yang lainnya bergantung pada kepemilikan dan modal yang dimiliki.

Media tidak bisa dipandang sesederhana sebagai sarana menyebarkan informasi. Media merupakan organisasi kompleks dan penting dalam masyarakat.
Media merupakan sarana penting dalam menyampaikan sebuah ideologi. Menurut McQuail ada lima konsep utama dalam teori media marxist;

1. Teori Klasik Marx; media dipandang sebagai instrumen kelas dominan dan bagi kapitalis merupakan wadah untuk mencari keuntungan atau profit.

2. Teori Ekonomi Politik Media; teori ini lebih menyalahkan akan kepemilikan media, karena konten media menjadi sebuah komoditi yang dijual ke masyarakat. Informasi yang disampaikan tersebut dikontrol dan disesuaikan dengan keinginan pasar.

3. Frankfurt School; melihat media sebagai alat untuk mengonstruksi budaya dan tempat untuk menyampaikan ide. Sehingga, digunakan untuk menyampaikan ideologi kaum dominan dan informasi yang disampaikan bisa dimanipulai sesuai keinginan kelas dominan.

4. Teori Hegemoni; hegemoni merupakan dominasi ideologi yang sudah dimanipulasi. Ideologi dominan yang merupakan kepentingan kelas tertentu disampaikan melalui media.

5. Pendekatan Sosiokultural; pendekatan yang lebih sering disebut dengan cultural studies. Fokus pada pembahasan makna kultural yang ada di media, melihat bagaimana konten media diinterpretasikan tidak hanya dari kelas dominan namun juga kelas proletar (Littlejohn, 2002: 309).

Marx merupakan salah satu tokoh penting dalam pembahasan kritik media dalam komunikasi. Ide dan gagasannya banyak menjelaskan terkait Komunikasi global, pekerja media, globalisasi dan media, media alternatif, kapital media, monopoli media, dialektika informasi. Teori Karl Marx berguna untuk mengidentifikasi konstruksi pada media dan komunikasi yang 
didasarkan pada kajian kapitalisme (Fuchs, 2009).

Menurut McChesney (2007), mengatakan bahwa teori Marx sangat berguna pada ilmu komunikasi, pemikiran Marx menjadi saran untuk menjelaskan beberapa aspek, antara lain;

1. Kritik akumulasi capital atau modal dalam industri budaya;

2. Kritik akan komoditas fetisisme;

3. Kritik akan ideologi yang menjadi legitimasi kekuasaan dominan (McChesney, 2007, 53-55)

Hasil pemikiran intelektualitas Marx daripada wujud politik praksis yang diilhami oleh Karl Marx melalui Marxisme pada negara-negara kesatuan Uni Sovyet, The People's Republic of China, dan Cuba. Revolusi Rusia Lenin pada tahun 1917 menandai titik balik dalam perhatian berikan kepada Marxisme. Setelah itu, tulisan-tulisan Marx menjadi sebuah gerakan bawah tanah kompleks yang kuat, ia menekankan pada masyarakat tertindas dan berusaha untuk membawa perubahan sosial dengan cara yang manusiawi.

\section{Media Menurut Marx}

Pemilik modal melakukan investasi pada media dan hal ini jelas mempengaruhi produksi konten media. Informasi yang disampaikan media menjadi sebuah komoditas bisnis yang terus dijadikan alat mencari keuntungan atau profit. Hal ini bisa dilihat dalam prakteknya program yang dibuat media cenderung seragam karena ingin mengikuti keinginan pasar, karena pasar adalah penentu pembuat iklan menganalisis keuntungan yang akan diperoleh. Semakin banyak masyarakat yang menyaksikan program tertentu dalam waktu tertentu menjadi tolok ukur keberhasilan iklan yang akan dipasang. Sehingga hal ini juga memunculkan istilah prime time, waktu dimana acara banyak dilihat dan iklan banyak pula muncul.

Beberapa konsep yang dapat kita jadikan sebagai pijakan dalam kajian marx akan media adalah:
- Pada level produksi: (1) Teknologi media sebagai teknologi dalam industri media; (2) Kapital atau faktor ekonomi merupakan fokus dari media; (3) Pekerja media dinilai sebagai salah satu alat produksi dalam kapitalisme media;

- Pada level sirkulasi: (1) Teknologi transmisi merupakan sarana infrasturktur media; (2) Media sebagai sarana iklan; (3) Media sebagai sarana perdagangan global; (4) Media sebagi sarana sentralisasi kapital;

- Pada level sirkulasi pesan melihat Media sebagai sarana penyampaian ideologi.

Pusat perhatian teori Marx bicara mengenai histori materialisme meliputi beberapa konsep berikut: proletariat, sosialisme, komunisme, perjuangan kelas, hegemoni, dan alienasi. Teori tersebut akan lebih dimanfaatkan untuk memperjuangkan manusia dalam menciptakan dunia yang lebih baik. Pada tataran teori di level sosial ekonomi makro diharapkan oleh Marx tidak hanya melampaui agregrasi sebagai perubahan di tingkat mikro atau individu (lebih mengarah pada sudut pandang sosiologi daripada sosio psikologis).

Marx dan kelompok teori yang dikembangkan hingga berbagai pengikut aliran teori kritisnya saat ini menjadi sumber ide dan konsep pemikiran empiris. Ilmuwan kritis berfokus pada isu kepemilikan dan kontrol media massa, kemudian diadaptasi menjadi topik penelitian empiris yang dilakukan oleh Paul F. Lazarfeld yang terjun di ranah ilmu komunikasi dengan menekankan pada efek komunikasi. Demikian pula peranannya dalam mewarnai tantangan intelektual di Amerika, dimana fenomena komunikasi dipelajari oleh ilmuwan kritis dengan pendekatan metodologi ilmuwan empiris.

Ilmuwan kritis dan ilmuwan empiris melihat aturan yang berbeda dalam komunikasi massa di masyarakat. Ilmuwan kritis berpikir bahwa media massa digunakan untuk mengontrol masyarakat, 
sedangkan ilmuwan empiris melihat media dapat digunakan untuk membantu mengurangi masalah sosial di masyarakat dan menjadi hal utama dalam perubahan sosial. Isu krusial dari ilmuwan kritis adalah siapa yang memiliki dan mengontrol media massa yang dikenal dengan pandangan makro, sedangkan ilmuwan empiris menekankan efek media massa terhadap individu khalayak media sebagaimana pandangan mikro.

Media massa inilah yang banyak dikritik oleh Marxist, neo-marxist, termasuk critical school of communication. Selanjutnya, diketahui pula sebagai bagian besar yang di dalamnya terdapat pemikiran Frankfurt School (1960) dan institusi penelitian sosial (1923), yaitu: Erich Fromm, Walter Benjamin, dan Jurgen Habermas.

Para pemikir the Frankfurt school mengkritisi gagasan klasik Marx dan mencoba meminjam dari mazhab pemikiran Freud untuk mengisi apa yang dianggap kurang dari Marx. Mereka mencoba menambahkan tingkatan makro penjelasan Marx mengenai perubahan sosial dengan tingkatan mikro dari aliran psikologi sosial menurut Freud terhadap seorang individu. Erich Fromm sebagai salah seorang pengikut aliran Marx, mencoba untuk melengkapi kerangka pikir Marx dengan pemikiran Freud yang mengadaptasi stuktur sosial sebagai anugerah yang diperoleh seseorang individu.

Marx tidak melibatkan faktor psikologis, namun justru menjelaskan faktor ekonomi sebagai determinasi struktur sosial. Fromm berpikir bahwa sosialisasi dalam keluarga pada seorang individu merupakan sarana psikologis yang penting dalam masyarakat, bahkan sosialisasi di masa remaja dapat berarti perubahan sosial.

Selain Fromm, terdapat Max Horkheimer, Theodor Adorno, Leo Lowenthal, dan Herbert Marcuse yang diklasifikasikan sebagai neo-marxis, dimana ideologi mereka adalah Marxist aliran kiri, dan sekaligus juga pengikut Freud atau yang dikenal sebagai Freudian. (Rogers, 1994:102-125)

\section{KESIMPULAN}

Teori media Karl marx menawarkan cara pandang untuk menganalisis media dengan sejumlah konsep kunci; media sebagai cara produksi, media sebagai amplifier, hegemoni ala Gramsci, sampai pada level text reading ala Stuart Hall.

Karl Marx memang belum mengenal pers sebelum menjadi media massa yang sekarang, namun tradisi analisis Marxist terhadap media dalam masyarakat kapitalis masih terus relevan. Kekuasaan adalah inti dari penafsiran Marx mengenai media massa. Walaupun beragam, inti dari pemikirannya adalah media merupakan instrumen bagi kelompok penguasa untuk mengontrol. Teori kapitalisme terus menerus mengupayakan hubungan langsung antara kepemilikan ekonomi dan penyebaran pesan yang meneguhkan legitimasi dan dari nilai masyarakat kelas.

Teori Karl Marx melihat keberadaan media, ditekankan pada konsep dialektika, dimana sering terjadi adanya konflik atau pertentangan dalam media. Konsep tesis, sintesis, dan antitesis terus muncul dalam media. Media diasumsikan sebagai arena pertarungan ideologi berbagai kelas. Media dianggap memiliki kerangka interpretasi yang sesuai dengan budaya dominan.

Pembahasan media dalam teori dialektika yang digagas oleh Max adalah bahwa Marx melihat bahwa dalam masyarakat selalu muncul pertentangan makna yang diberikan media. Masyarakat kaum proletar melihat media massa sebagai institusi yang menyediakan pekerjaan yang merupakan bagian konsepsi tesis, sedangkan media massa merupakan sarana atau alat kepentingan kapitalis dalam mengeksploitasi proletar sebagai konsepsi antitesis. Kaum proletar akan melakukan revolusi yang berimplikasi pada perjuangan meraih kesetaraan kelas yang menjadi konsepsi sintesis.

Teori Marx cenderung menekankan pada peran serta lembaga media massa dalam mempertahankan status quo yang membedakan dengan paham liberal dan menekankan peran media massa tersebut 
dalam usaha pengembangan kebebasan berbicara. Marx memandang media massa dimiliki oleh kalangan borjuis saja dan dioperasikan untuk kepentingan kelas mereka.

Teori Marx fokus pada ideologi yang membantu untuk mengikis adanya ekonomisme dan pengendalian kaum penguasa terhadap segala sesuatu dengan paham kapitalisme mereka. Media massa dipandang pesimis, karena begitu 'sering' digunakan untuk memantapkan kontrol terhadap masyarakat terutama oleh kelaskelas penguasa. Isu utamanya adalah siapa yang memiliki dan mengendalikan media massa? serta siapa yang diuntungkan dan siapa yang dirugikan dengan adanya pengendalian media massa? Kekuatan ekonomi yang dimiliki dan dikendalikan kaum penguasa telah menentukan perubahan sosial di masyarakat.

Kelompok borjuis sebagai "the ruling class", (kelas yang berkuasa) tidak sekedar menguasai kekuasaan ekonomi, tetapi juga menggerakkan kekuasaan lewat agen negara dan kekuasaan ideologis yang dimilikinya karena realitas "kesadaran" dikuasai kelompok yang berkuasa atau menguasai berbagai sumber kekuasaan. Umumnya mereka yang berkuasa ini mapan secara finansial dan/atau memiliki jabatan strategis sebagai pemangku kebijakan atau yang sering disebut the ruling class. Kaum proletariat harus membangun kesadaran baru untuk merlakukan penghapusan hak milik pribadi melalui perjuangan kelas (class struggle).

Revolusi kelompok sosialis yang digerakkan oleh kelas proletar adalah jalan satu-satunya menuju masyarakat ideal tanpa kelas. Revolusi sendiri kata Marx dan Engels adalah:

\footnotetext{
"delibarate and intentional overthrow of one class by another - of a ruruling class by a subordinate one and of the economic, political and social interest associated with the dominant class and their mode of production" (Lowes, 2006:208).
}

Adapun tujuan revolusi, menurut Marx ialah, bagaimana menghapuskan sistem hak milik pribadi. Hapusnya hak milik pribadi berarti alat-alat produksi (means of production) menjadi milik bersama. Implikasi politiknya adalah berakhirnya eksploitasi manusia atas manusia lainnya. Dengan demikian akan terbentuklah suatu masyarakat tanpa kelas (classless) seperti cita-cita luhur yang menjadi impian Marx bersama pengikut aliran Marxisme di ujung sejarah manusia.

Upaya menuju keluhuran tersebut terdapat kondisi dimana terjadi dialektika. Dialektika merupakan proses interaksi di antara kekuatan-kekuatan yang saling bertentangan, kemudian pertentangan ini melahirkan tahap perkembangan yang lebih tinggi berupa sebuah kekuatan pendorong perubahan. Oleh karena itu, perubahan historis merupakan konsekuensi logis dari kontradiksi internal di dalam "cara berproduksi" yang tercermin dalam antagonisme kelas". (Heywood, 2007:56)

\section{DAFTAR PUSTAKA}

Barker, Chris. 2008. Cultural Studies: Theory and Practice $3^{\text {rd }}$ Edition. London: Sage Publication

Callinicos, Alex. 2004. The Revolutionary Ideas of Karl Marx. London: Bookarks Publications Ltd

Fuchs, Christian. 2009. International Journal of Communication; Some Theoretical Fondations of Critical Media Studies: Reflections on Karl Marx and the Media. University of Salzburg

Heywood, Andrew. 2007. Political Ideologies: An Introduction. New York: Palgrave Macmillian

Littlejohn, Stephen W. 2002. Theories of Human Communication $7^{T H}$ Edition. California: Thomson Wardsworth

Jurnal Bricolage Vol. 2 No. 2 
Lowes, David E. 2006. The Anticapitalist Dictionary: Movements, Histories, and Motivations. USA: Palgrave Macmillan

McChesney, Robert. 2007. The Communication Revolution. Ney York: Nw Press

McQuail, Dennis. 2010. Mass Communication Theory $6^{\text {th }}$ Edition. London: Sage Publication Ltd
Rogers, Everett M.. 1994. A History of Communication Study: A Biographical Approach". USA, Canada: Maxwell Macmillan

Suseno, Franz Magnis 1999. Pemikiran Karl Marx dari Sosialisme Utopis ke Perselisihan Revisionisme. Jakarta: PT Gramedia Pustaka Utama. 